\title{
Wind-Driven Response of the Northern Indian Ocean to Climate Extremes*
}

\author{
TOMMY G. JENSEN \\ International Pacific Research Center, University of Hawaii at Manoa, Honolulu, Hawaii
}

(Manuscript received 14 June 2005, in final form 22 March 2006)

\begin{abstract}
Composites of Florida State University winds (1970-99) for four different climate scenarios are used to force an Indian Ocean model. In addition to the mean climatology, the cases include La Niña, El Niño, and the Indian Ocean dipole (IOD). The differences in upper-ocean water mass exchanges between the Arabian Sea and the Bay of Bengal are investigated and show that, during El Niño and IOD years, the average clockwise Indian Ocean circulation is intensified, while it is weakened during La Niña years. As a consequence, high-salinity water export from the Arabian Sea into the Bay of Bengal is enhanced during El Niño and IOD years, while transport of low-salinity waters from the Bay of Bengal into the Arabian Sea is enhanced during La Niña years. This provides a venue for interannual salinity variations in the northern Indian Ocean.
\end{abstract}

\section{Introduction}

In recent years there has been increased focus on the interannual variability of sea surface temperature (SST) in the Indian Ocean due to the discovery of the Indian Ocean dipole (IOD) (Saji et al. 1999), alternately named the Indian Ocean "Zonal Mode" (IOZM) (Webster et al. 1999; Clark et al. 2003). Whether the IOD is related to El Niño (e.g., BaqueroBernal et al. 2002) or not (Behera et al. 2003) is still controversial, but there is no doubt that forcing conditions and SST are unusual in the northern and tropical Indian Ocean during IOD years. In this paper, we will use the term IOD event for years with a positive dipole mode index (Saji et al. 1999) when SST anomalies are negative off Sumatra and positive in the western Indian Ocean. The case of negative IOD years when SST anomalies are reversed will not be considered here.

The main focus of research on the IOD has, so far, been on the east-west gradient in SST in the tropical Indian Ocean and the associated equatorial zonal wind

\footnotetext{
* School of Ocean Engineering Science and Technology Contribution Number 7103 and International Pacific Research Center Contribution Number IPRC-443.

Corresponding author address: Tommy G. Jensen, International Pacific Research Center/SOEST, University of Hawaii at Manoa, 1680 East West Rd., Honolulu, HI 96822.

E-mail: tjensen@hawaii.edu
}

stress, anomalous rainfall over East Africa, and its correlation to global atmospheric anomalies (e.g., Saji and Yamagata 2003a; Lau and Nath 2004; Shinoda and Alexander 2004). Studies of regional changes in the Indian Ocean general circulation are few and focus on the upwelling off Sumatra and the thermal structure along the equator (e.g., Murtugudde et al. 2000; Vinayachandran et al. 2002; Feng and Meyers 2003). Recently, Haugen et al. (2002) and Manghnani et al. (2003) used the Miami Isopycnal Ocean Coordinate Model to model general circulation of the Indian Ocean using the Comprehensive Ocean-Atmosphere Data Set (COADS) forcing. Both studies computed interannual variability at several sections and found strong variability in zonal transport across $80^{\circ} \mathrm{E}$ in general, with relatively strong (weaker) positive transport anomalies during La Niña (El Niño).

In recent model studies (Jensen 2001b) a 4.5-layer model with prognostic temperature, salinity, and mixed layer depth was forced by monthly climatological winds from the European Centre for Medium-Range Weather Forecasts and relaxed to surface temperature (Levitus and Boyer 1994) and salinity (Levitus et al. 1994). The model was used to investigate the Arabian Sea and Bay of Bengal water exchanges and the associated crossequatorial flows. However, it became apparent that this exchange was part of a much larger basinwide circulation with transport of low- and high-salinity water masses (Jensen 2003b). It was concluded that a clockwise cross-equatorial gyre circulation exists on the av-

DOI: 10.1175/JCLI4150.1 

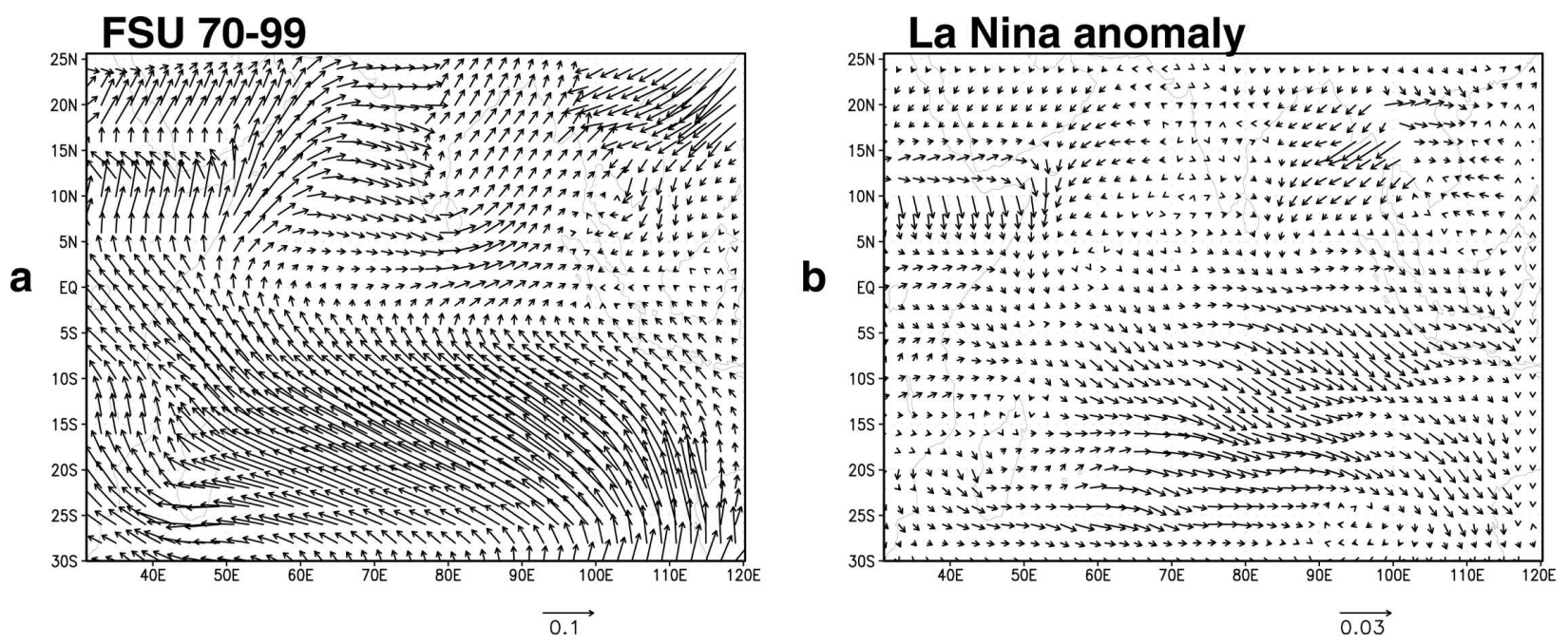

\section{EI Nino anomaly}
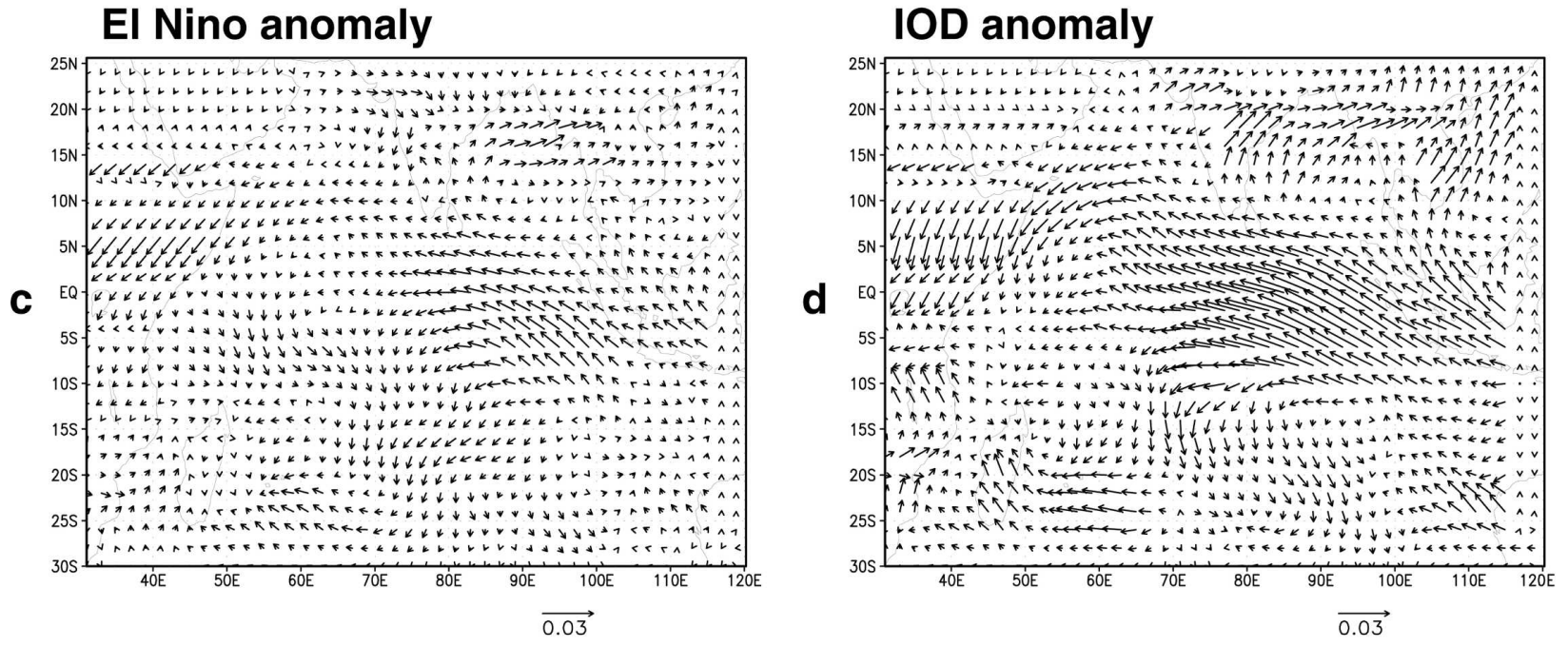

FIG. 1. (a) Annual mean wind stress of the FSU climatology, and corresponding wind stress anomalies for (b) La Niña, (c) El Niño, and (d) IOD. Units are $\mathrm{N} \mathrm{m}^{-2}$.

erage. The freshwater route in the Ekman layer follows the same pattern: A classical interior southward and southwestward flow closed by a northward western boundary current. The strong subsurface northward flow in the Somali Current, which has its origin in the southern Indian Ocean and the Indonesian Throughflow, provides a source for upwelling in the northern Indian Ocean. Since this water subsequently is advected southward by Ekman transport, a shallow overturning cell is part of this gyre circulation (Miyama et al. 2003).

In this paper, we discuss the wind-driven response of the cross-equatorial cell, with emphasis on the changes in the freshwater and high-salinity water exchanges with the Arabian Sea and the Bay of Bengal under climate extremes. The idea is to assume that El Niño,
La Niña, and IOD years each represents a different wind climate, so the equilibrium response can be found from model runs.

\section{Numerical model}

The Indian Ocean model is based on the multilayer upper-ocean model (Jensen 1991, 1993) extended to include prognostic temperature, salinity, tracers, and mixed layer physics (Jensen 1998a, 2001a, 2003a). In addition, lateral stresses are assumed to be proportional to the local deformation rate of the flow (Smagorinsky 1963). Diffusivity of temperature, salinity, and tracers is included using Laplacian diffusion with a constant diffusivity of $1000 \mathrm{~m}^{2} \mathrm{~s}^{-1}$.

The model is used here in a 4.5-layer configuration 


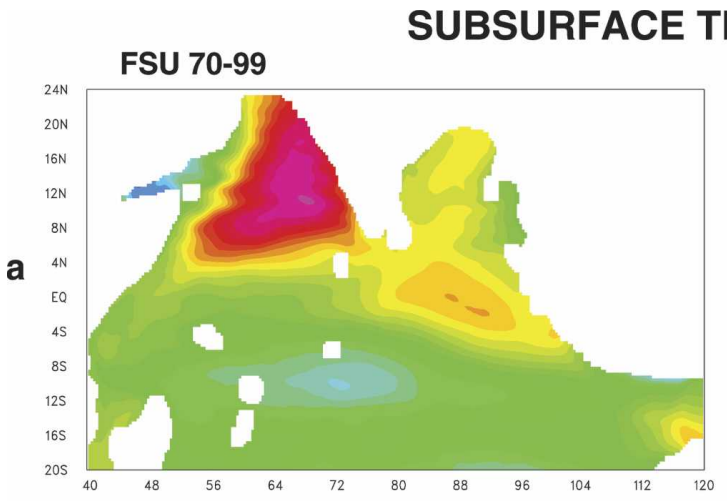

\section{MPERATURE}

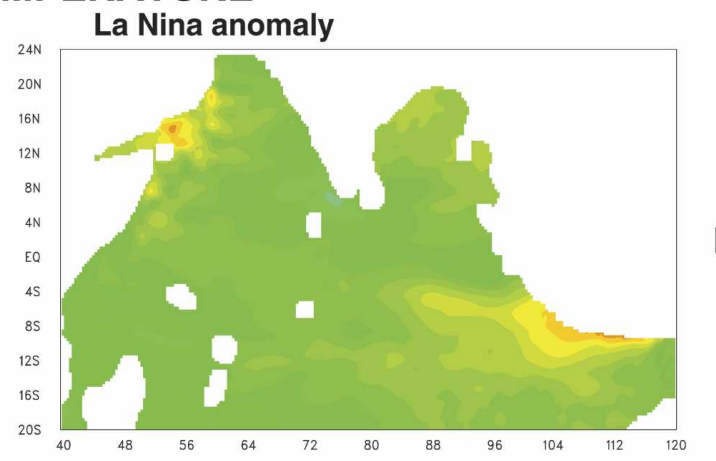

k
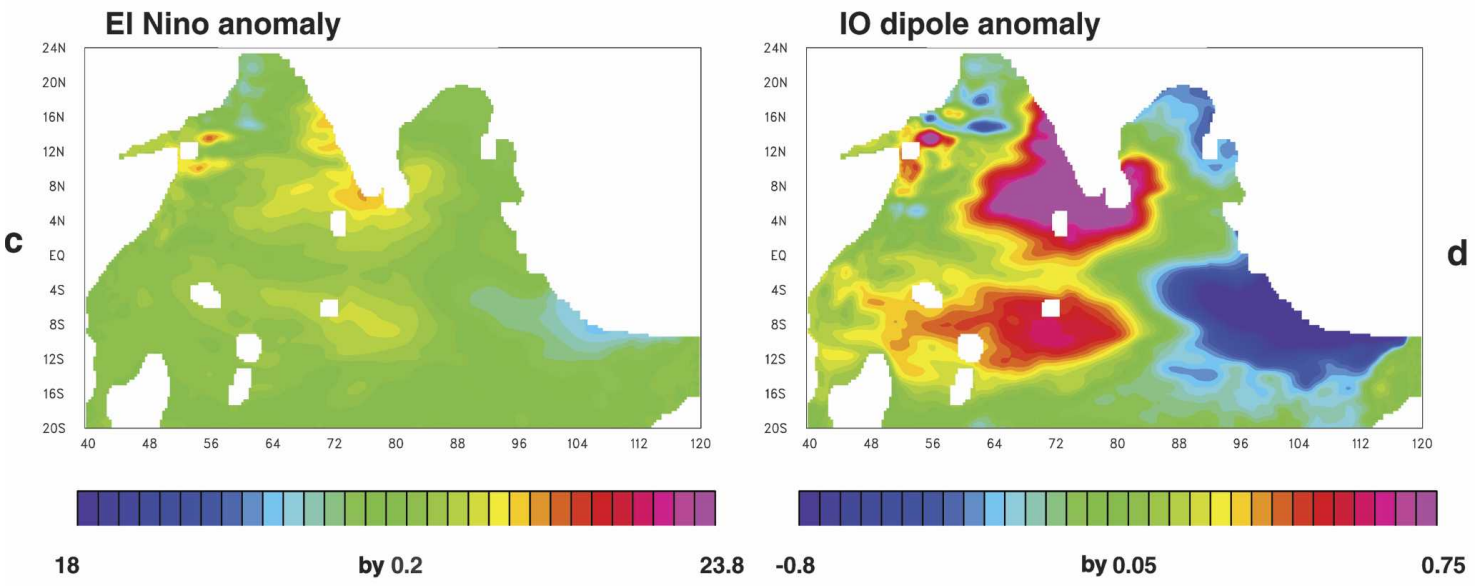

18

by 0.2

23.8

by 0.05

0.75
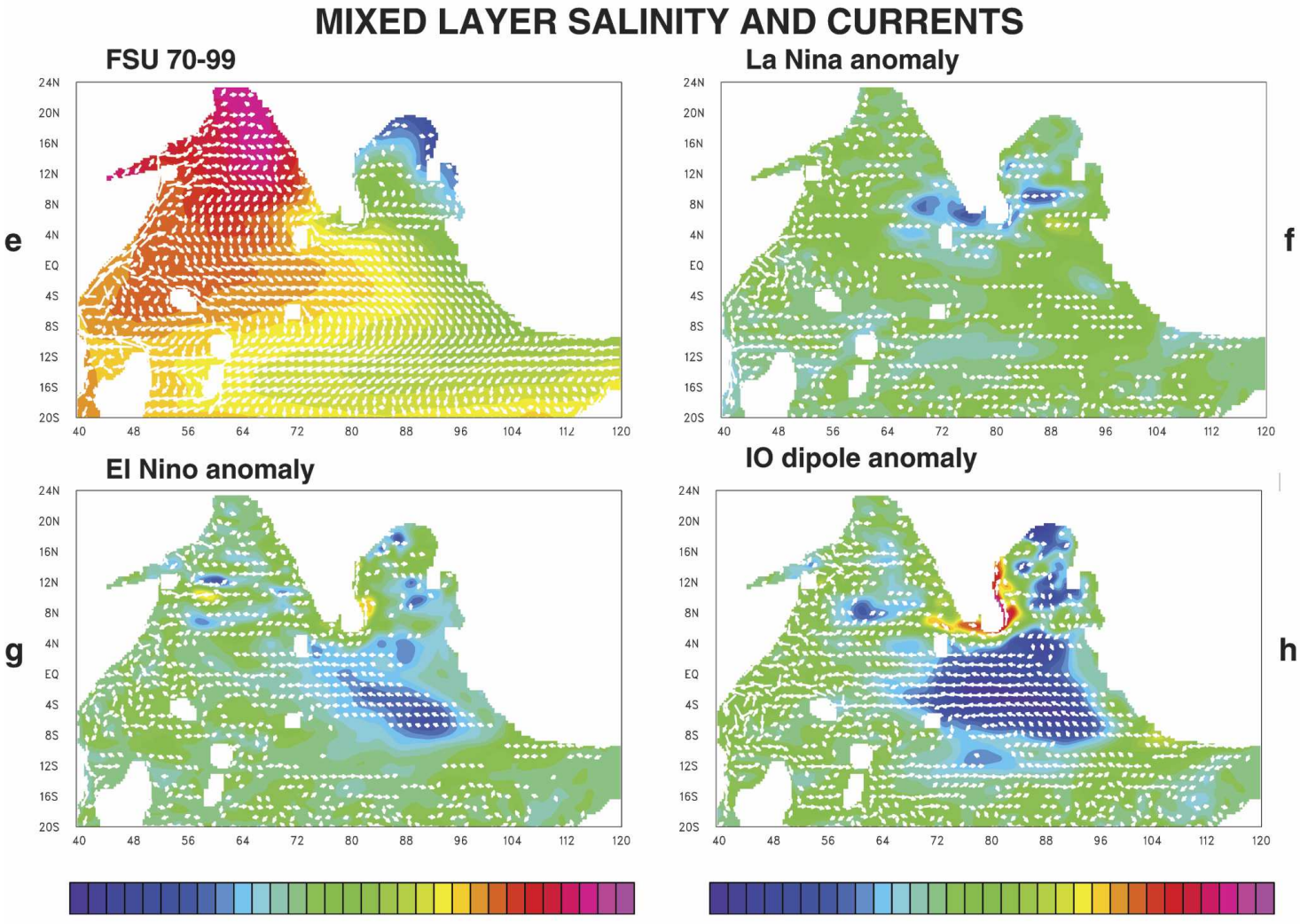
with a horizontal resolution of $13^{\circ}$. The average initial thickness is $80 \mathrm{~m}, 120 \mathrm{~m}, 250 \mathrm{~m}$, and $600 \mathrm{~m}$ for layers 1 to 4, respectively, and the deepest layer is infinitely deep. The model covers the Indian Ocean north of $30^{\circ} \mathrm{S}$. Open boundaries are present at the southern edge of the domain and to the Pacific Ocean at $120^{\circ} \mathrm{E}$. Using a general flow relaxation scheme (Jensen 1998b), the flow is relaxed toward a constant inflow from the Pacific of $10 \mathrm{~Sv}\left(\mathrm{~Sv} \equiv 10^{6} \mathrm{~m}^{3} \mathrm{~s}^{-1}\right)$ and toward an outflow of $40 \mathrm{~Sv}$ near the coast of Africa. The remaining $30 \mathrm{~Sv}$ is flowing into the Indian Ocean between $39^{\circ} \mathrm{E}$ and Australia.

\section{Wind stress forcing and initialization}

The Florida State University (FSU) pseudo-wind stress for 1970-99 has been interpolated to the model grid and the model has been run using composites for the Indian Ocean dipole mode years (1972, 1982, 1994, 1997), El Nino years $(1972,1976,1982,1986,1987,1991$, 1997), and La Niña years (1970, 1971, 1973, 1975, 1988, 1998).

Note that El Niño and dipole years overlap. As mentioned in the introduction, there is still a debate about to what extent the Indian Ocean dipole is independent of El Niño (Baquero-Bernal et al. 2002; Behera et al. 2003). For the years covered by the FSU wind stress analysis used as forcing only one IOD year (1994) did not coincide with an El Niño year. For this reason a composite pure IOD case could not be included in this study. Conversion from pseudo wind stress to wind stress was done using a constant drag coefficient of $1.5 \times 10^{-3}$.

Figure 1 shows the annual mean of the FSU wind stress and the annual mean anomalies for each of the extreme cases. The largest wind stress anomalies occur during IOD years during the boreal fall when strong southeasterly wind anomalies cross the equator in the eastern tropical Indian Ocean. While the spatial patterns of the annual average anomalies are similar for El Niño and IOD, the month to month anomalies differ, particularly during the boreal spring and early summer (e.g., Saji and Yamagata 2003b). During La Niña, the wind stress anomalies are typically in the opposite direction of those found during $\mathrm{El}$ Niño and IOD.
A periodic wind stress forcing was chosen to force the ocean model. In that way, the model is started from rest and forced in exactly the same way for all cases. While this is less realistic than using a continuous run from 1970 to 1999 , it eliminates the variance that may occur due to different initial conditions and differences between individual year wind forcing for each of the climate scenarios. This is particularly relevant for IOD cases since there are only four events. Averaging the winds leads to more robust results.

The model was initialized using the January temperature and salinity from Levitus and Boyer (1994) and Levitus et al. (1994) and initializing the off-equatorial currents to geostrophy with a level of no motion below layer 4 . Within $5^{\circ}$ of the equator a geostrophic initialization using the magnitude of the Coriolis force at $5^{\circ}$ was applied, while keeping the correct sign. This results in an unbalanced current near the equator. The model was integrated one year with $T$ and $S$ kept constant for one year, so the model is close to equilibrium at the start of year 2 .

To be consistent with the results in Jensen (2001b, $2003 \mathrm{~b}$ ), the surface temperature and surface salinity is chosen to be relaxed to the Levitus and Boyer (1994) and Levitus et al. (1994) climatology with an $e$-folding time of 6 days. Since rivers and runoff are not included in the model, a short time scale is required for adequate freshwater fluxes in coastal regions with high precipitation such as the Bay of Bengal. Providing this forcing means that the differences found between the climate scenarios are directly caused by wind-driven differences for the surface layer. To explore the evolution of tracers during an extreme year, the model was spun up for 6 years with monthly mean winds for each composite event. After that time the solution only shows minor differences from year to year. Assuming a periodic solution enables us to model float paths for several years using the model output for one or two years.

\section{Subsurface temperature anomalies}

Below the mixed layer the temperature is allowed to evolve unconstrained. Figures $2 \mathrm{a}-\mathrm{d}$ show the layer-2

FIG. 2. (a) Annual mean subsurface (layer 2) temperature during year 5 of the integration for the FSU climatology, and corresponding subsurface temperature anomalies for (b) La Niña, (c) El Niño, and (d) IOD. Units are degrees Celsius. (e) Annual mean mixed layer salinity and volume transport during year 5 of the integration for the FSU climatology, and corresponding salinity and transport anomalies for (f) La Niña, (g) El Niño, and (h) IOD. Units are practical salinity units (psu) for salinity (left color bar) and salinity anomalies (right color bar). The length of each vector is proportional to the square root of the magnitude of the layer-integrated velocity. Unit is $\mathrm{m} \mathrm{s}^{-0.5}$. Only every fourth vector in each direction is shown. 


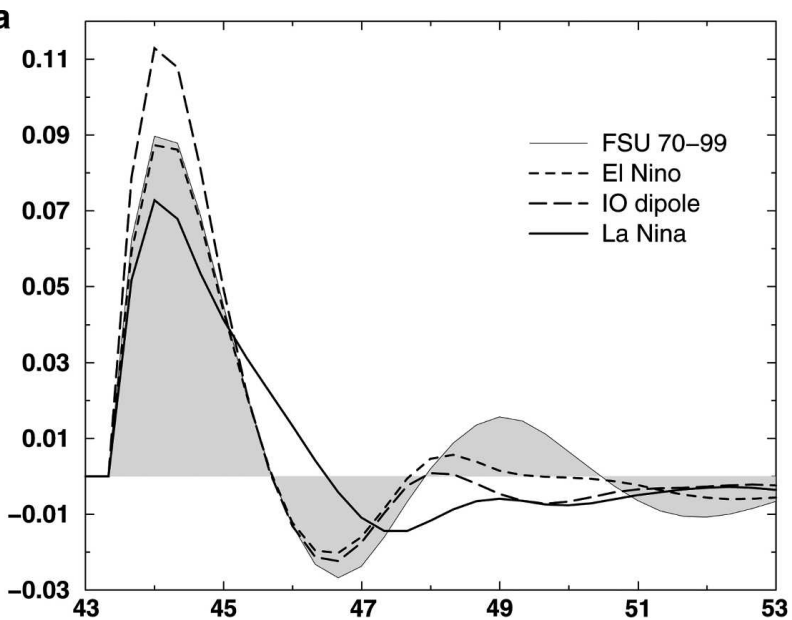

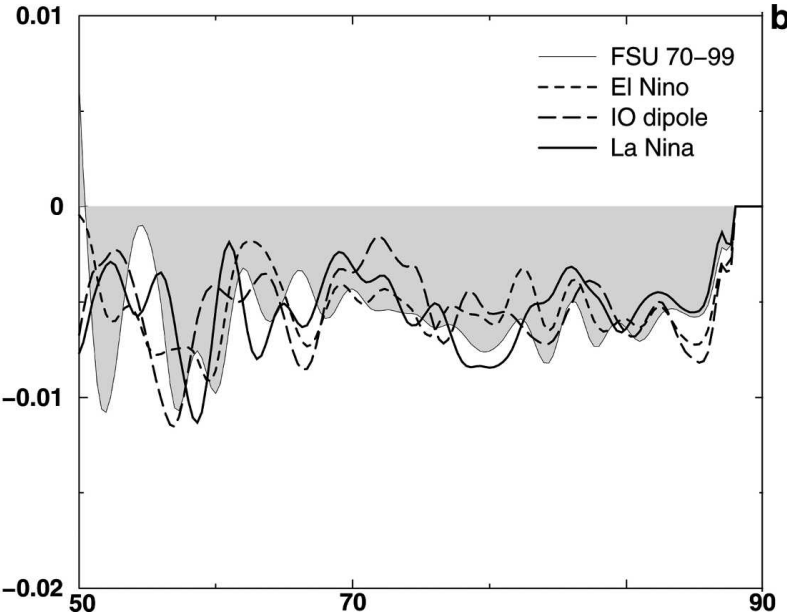

FIG. 3. Annual mean volume transport along the equator during year 5 of the integration (a) across the Somali Current region and (b) across the interior to the eastern boundary. Unit is $\mathrm{m}^{2} \mathrm{~s}^{-1}$. The case forced with FSU 1970-99 climatology is filled in gray. The La Niña transports are shown as solid blue line, El Niño is shown as dashed line, and IOD is shown as long-dashed line.
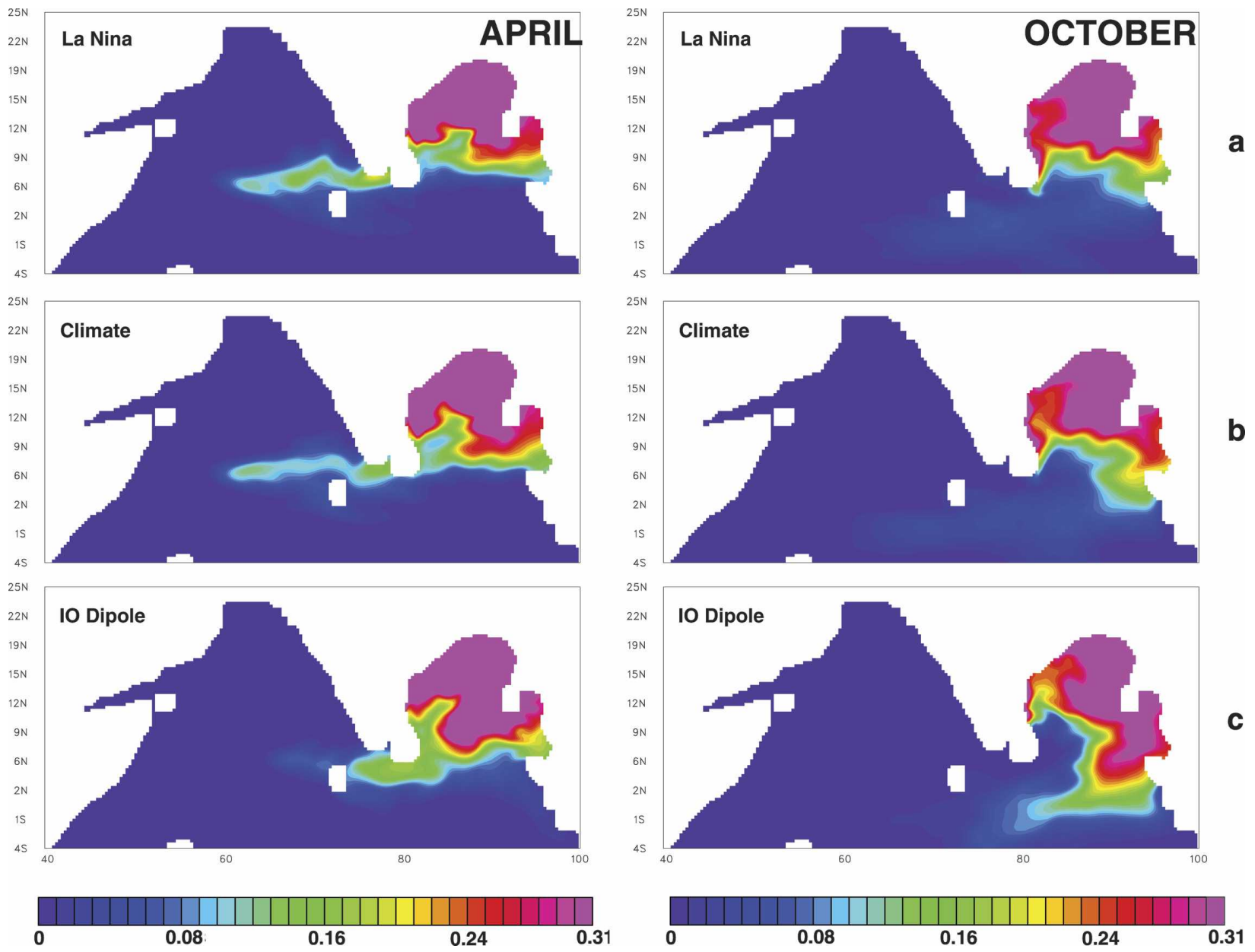

FIG. 4. Concentration of tracer released in the Bay of Bengal during (left) April and (right) October in year 5 of the integration shown for three climatologies: (a) La Niña, (b) FSU 1970-99, and (c) IOD. 
(about 80 to $200 \mathrm{~m}$ ), annual averaged temperature for the FSU climatology, and the corresponding subsurface anomalies for La Niña, El Niño, and IOD. The major difference from climatology is found in IOD years. As discussed in the introduction, the cooling off Java and Sumatra is the dominant IOD temperature response due to abnormally strong southeasterly winds between northern Australia and northern Sumatra. The wind anomaly briefly appears in April and reemerges for a three-month period from June through August. A weaker subsurface cooling is seen during El Niño at the same location. Second, the subsurface cool temperature dome in the southern Indian Ocean from $60^{\circ}$ to $80^{\circ} \mathrm{E}$ in the vicinity of $10^{\circ} \mathrm{S}$ (e.g., Xie et al. 2002) disappears during IOD years, when winds are less favorable for upwelling in that region. Rao and Behera (2005) noted the absence of this thermal dome during IOD and the associated increase in SST in the western Indian Ocean. The third significant subsurface temperature anomaly is found in the northern part of the Bay of Bengal. During the IOD scenario, there is a cooling by $0.4^{\circ} \mathrm{C}$ and somewhat less during El Niño. Conversely, a warming of $0.2^{\circ} \mathrm{C}$ is found during La Niña. An intensification of the eastward zonal wind stress in the northern Bay of Bengal during the southwest monsoon is found during IOD years. This causes an increased southward Ekman component, which induces upwelling along the coast. Rao et al. (2002b) found this subsurface cooling in the eastern Bay of Bengal in XBT observations from 1997 as well as in their OGCM model run of that event. They also noted that the winds were too weak to break down the strong stratification in that region, so negative SST anomalies were absent in the Bay of Bengal in 1997.

\section{Salinity and transport anomalies in the mixed layer}

In the following sections advection of salinity and tracers are discussed in detail for selected cross sections. Figures $2 \mathrm{e}-\mathrm{h}$ show the annual mean transports and salinity for the FSU run and the anomalies of these quantities from the annual mean of the runs when forced by the El Niño, La Niña, and IOD composites. Large salinity anomalies are found in the vicinity of Sri Lanka. They are associated with advection of Bay of Bengal water and Arabian Sea water and will be discussed below. In the central equatorial Indian Ocean a large area with negative salinity anomalies appears in the El Niño and IOD case. This is caused by anomalous advection of low-salinity water from the eastern equatorial Indian Ocean. The mixed layer becomes shallower and low-salinity water is advected westward and poleward by divergent Ekman flow forced by easterly

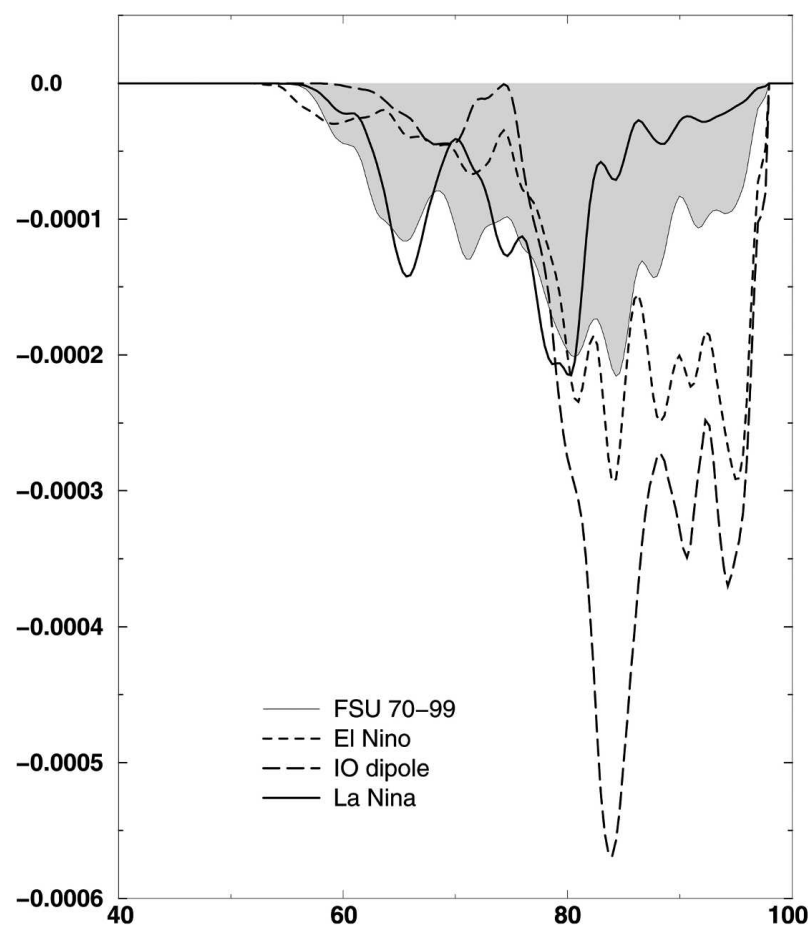

Fig. 5. Annual mean transport of Bay of Bengal tracer flux along the equator during year 5 of the integration for cases forced with FSU 1970-99 climatology (gray filled), La Niña climatology (solid line), El Niño climatology (dashed), and IOD climatology (long-dashed). Unit is $\mathrm{m}^{2} \mathrm{~s}^{-1}$.

wind anomalies. In the case of La Niña there is a weak convergent Ekman flow in the area and no significant change in mixed layer salinity.

\section{Cross-equatorial volume transport}

The most prominant feature of the northern Indian Ocean circulation is its complete reversal of the surface flow with the changing monsoons. However, the dominant southwest monsoon causes a clockwise annual mean flow, which is followed by drifters (Jensen 2003b). The first question that arises is if this annual mean circulation is changed during the extreme wind forcing cases. Figure 3 shows the cross-equatorial volume transport in the mixed layer across the Indian Ocean. For clarity, different scales are used for the Somali Current region in the west and the central and eastern Indian Ocean. East of the boundary current region there are changes in the positions of local maxima of poleward transports. Most importantly, there is enhanced southward transport along the eastern edge of the basin during IOD and El Niño.

In the Somali Current there is a significant increase in the peak northward transport to $0.11 \mathrm{~m}^{2} \mathrm{~s}^{-1}$ during an IOD year and a significant decrease in transport during La Niña to $0.07 \mathrm{~m}^{2} \mathrm{~s}^{-1}$. The peak is $0.09 \mathrm{~m}^{2} \mathrm{~s}^{-1}$ 

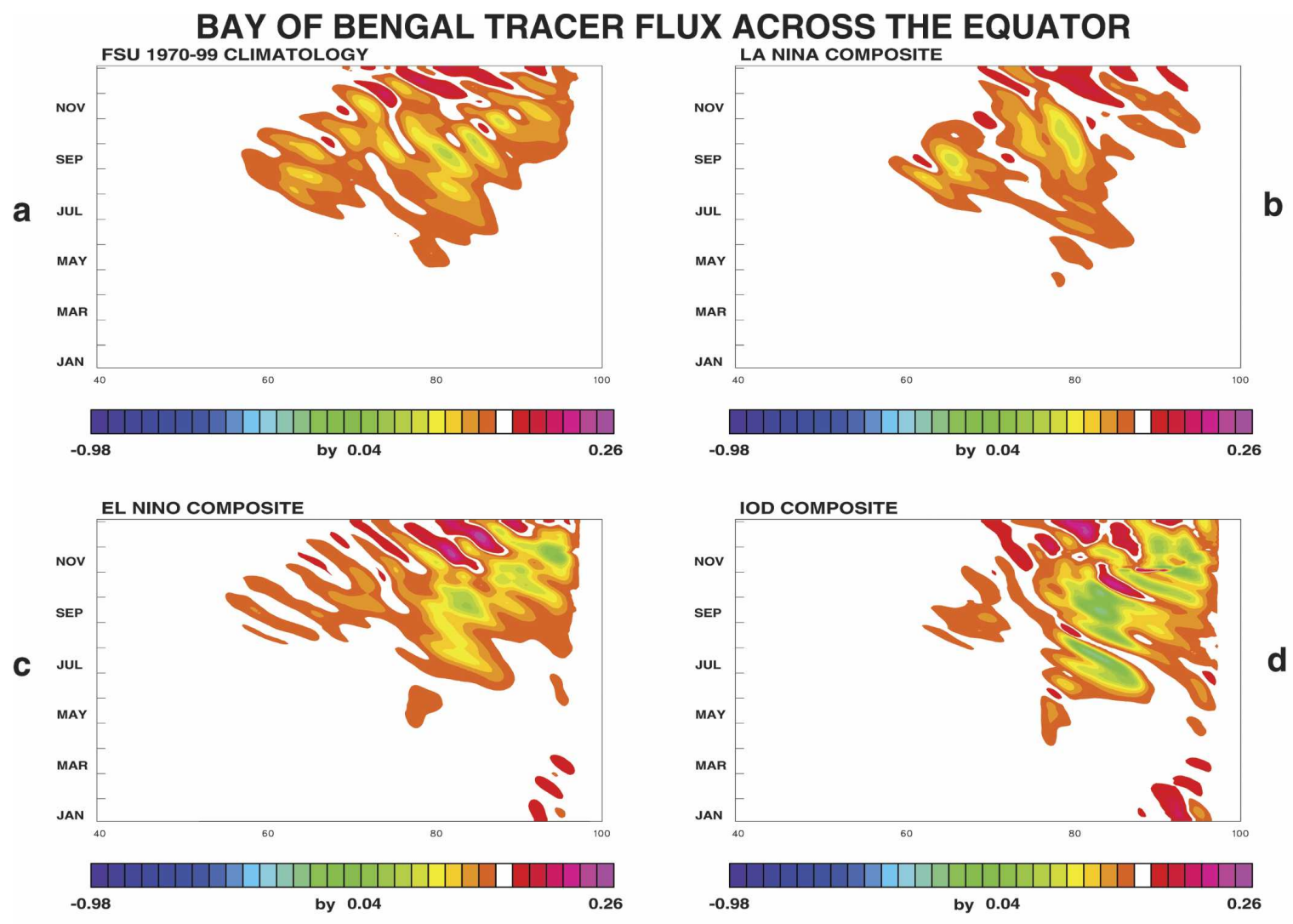

BAY OF BENGAL TRACER FLUX ACROSS 7N
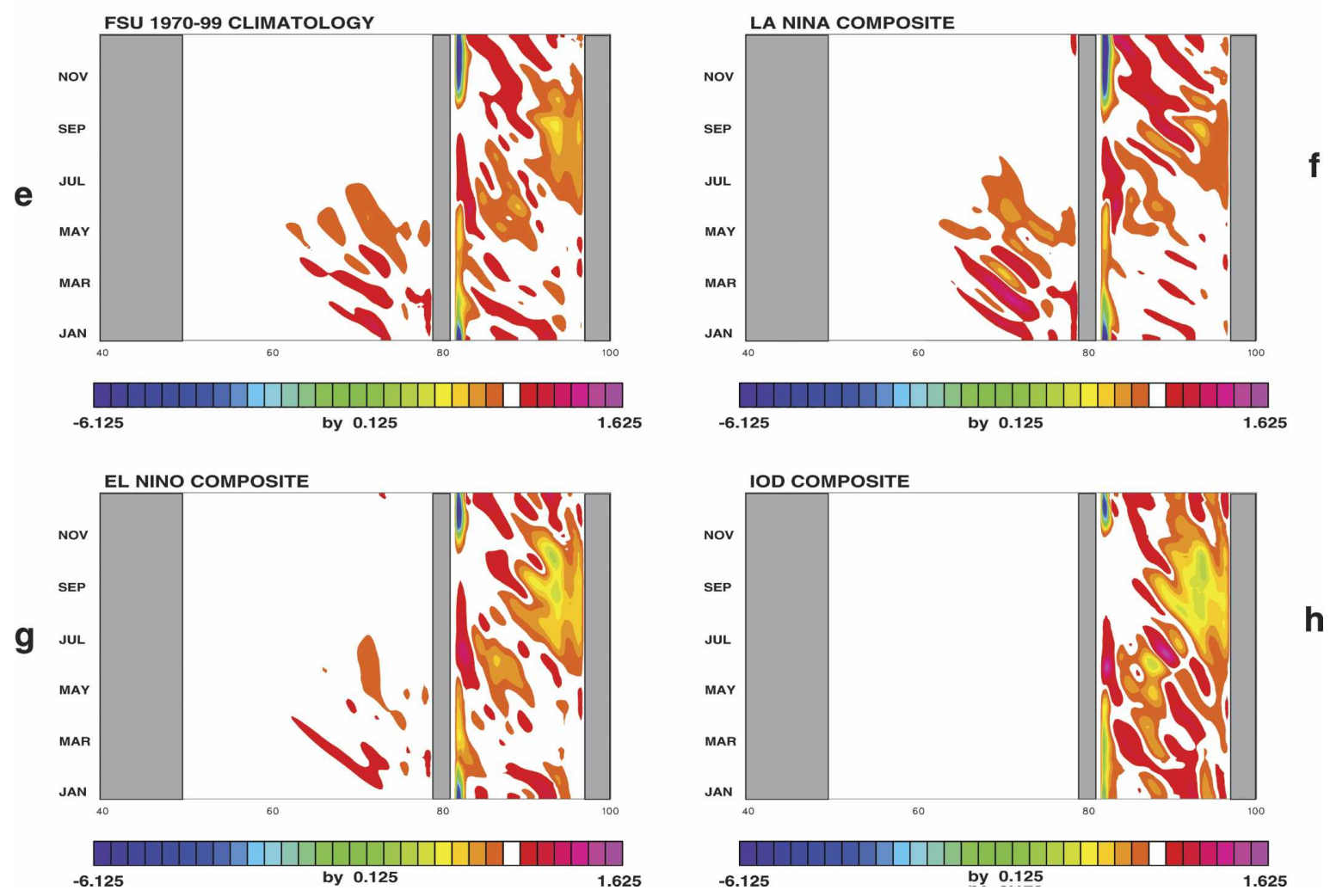
on average and in El Niño years. This is the first indication that IOD years would enhance the clockwise cross-equatorial gyre and that La Niña will tend to slow it down. This leads us to the hypothesis that an enhanced freshwater or low-salinity circulation takes place during the IOD and perhaps during El Niño years.

\section{Tracers and salinity anomalies}

Passive tracers have the advantage that there are no other sources than those in the controlled release. In contrast, water masses with relative low salinity have sources of freshwater in the Bay of Bengal, the equatorial region, and from the Pacific Ocean via the Indonesian Throughflow. In the model, these and other surface sources are included by the relaxation to surface salinity. By introducing passive tracers for the water masses we are able to trace water masses and compare them to salinity anomalies, while avoiding the ambiguity of sources.

Two passive tracers were released on 15 January after 3 years of integration and followed for 3 years. One tracer, the Arabian Sea tracer, was released with an initial concentration of $100 \%$ in layer 2 , which is below the mixed layer. This tracer marked water in layer 2 in the Arabian Sea north of $9.6^{\circ} \mathrm{N}$. Upwelling during the southwest monsoon rapidly entrained the passive tracer into the mixed layer. This tracer represents the highsalinity Arabian Sea water. A second tracer, the Bay of Bengal tracer, had initially a $100 \%$ concentration in the mixed layer in the Bay of Bengal north of $11.3^{\circ} \mathrm{N}$. It represents the low-salinity Bay of Bengal water.

To help distinguish high- and low-salinity waters we define the salinity anomaly locally across a section. Along the equator we use the definition

$$
S^{\prime}=S-\bar{S}^{t}
$$

where $\bar{S}^{t}$ is the annually averaged, but zonally varying, reference salinity over the cross section (Jensen 2003b). It is allowed to vary with longitude because of large differences in annual mean salinities between the eastern and western Indian Ocean.

Along the two sections at $7^{\circ} \mathrm{N}$, we use

$$
S^{\prime}=S-\bar{S}^{\phi t},
$$

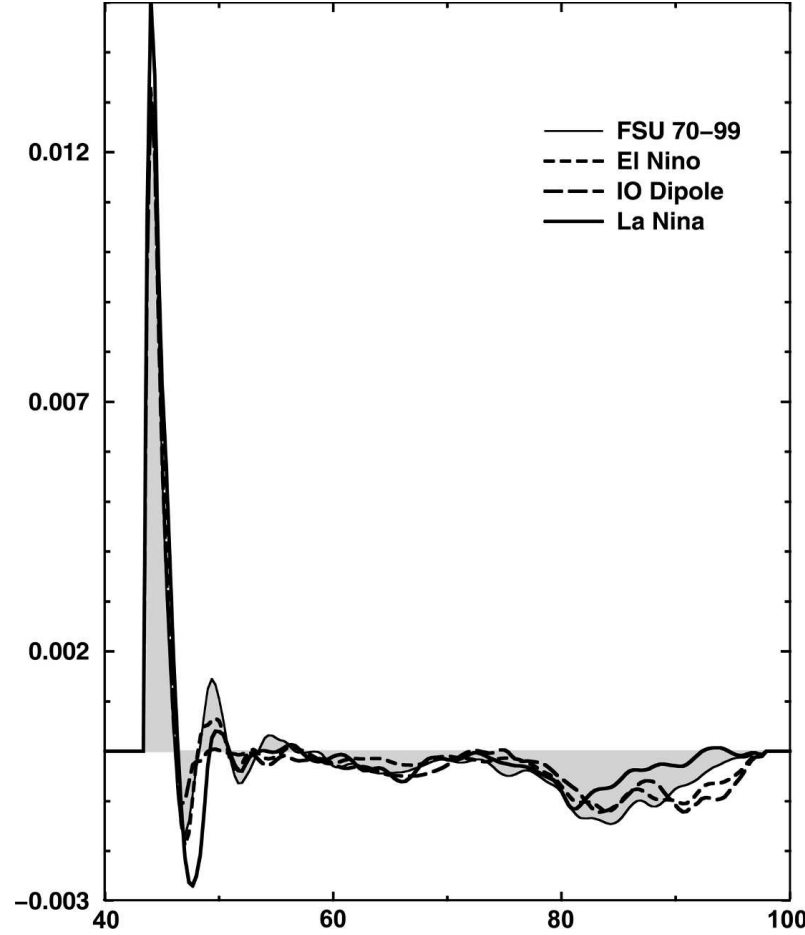

FIG. 7. Annual mean transport of low-salinity water along the equator during year 5 of the integration. The case forced with FSU 1970-99 climatology is gray filled. La Niña transports are shown as solid line, El Niño is shown as dashed line, and IOD is shown as long-dashed line. Unit is $\mathrm{psu}^{2} \mathrm{~s}^{-1}$.

where $\bar{S}^{\phi t}$ is the annually and zonally averaged salinity. The spatial average is taken across each section separately. For the Bay of Bengal this reference salinity is 33.44 psu, while it is 35.26 psu for the Arabian Sea.

For each section, the salinity transport is separated into a low-salinity flux and a high-salinity flux following the method by Jensen (2001b). The high-salinity anomaly flux is defined as

$$
F_{\mathrm{HS}}=V S^{\prime} \Theta\left(S^{\prime}\right)
$$

where $V$ is the meridional volume transport component in the mixed layer and $\Theta$ is the unit step function, which is one for positive arguments and zero elsewhere. We define the low-salinity anomaly flux as

$$
F_{\mathrm{LS}}=V S^{\prime}\left(1-\Theta\left(S^{\prime}\right)\right)
$$

$\leftarrow$

FIG. 6. Longitude-time plot of northward flux of Bay of Bengal tracer anomalies in the mixed layer at the equator during year 5 of the integration forced with wind stress based on (a) FSU 1970-99 climatology, (b) La Niña composite, (c) El Niño composite, and (d) IOD composite. The contour interval is $0.04 \mathrm{~m}^{2} \mathrm{~s}^{-1}$. (e)-(h) Same as in (a)-(d), but at $7^{\circ} \mathrm{N}$. The contour interval is $0.125 \mathrm{~m}^{2} \mathrm{~s}^{-1}$. White indicates zero flux. 

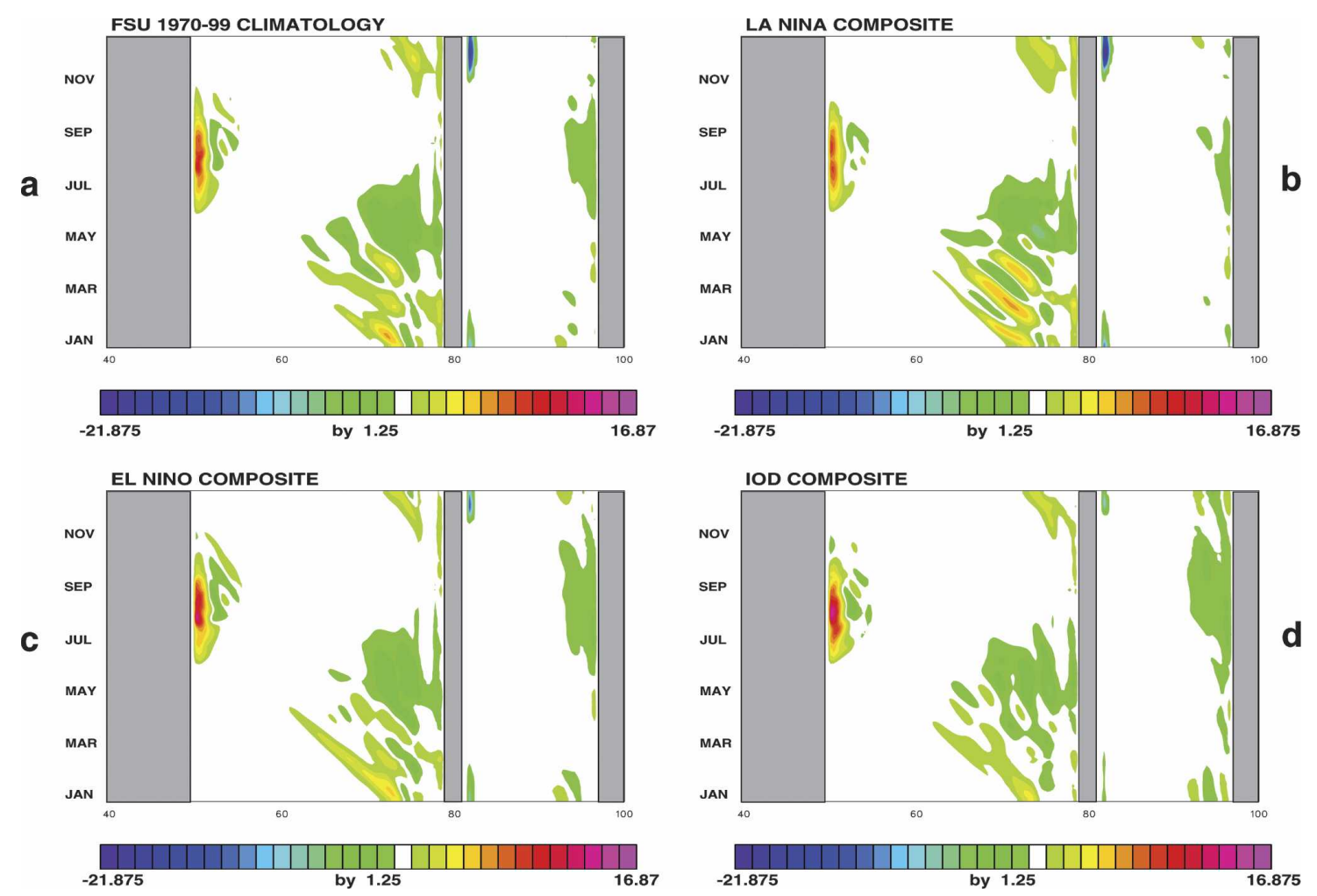

FIG. 8. As in Fig. 6 but for low-salinity water in the mixed layer at $7^{\circ} \mathrm{N}$. The contour interval is $1.25 \mathrm{psu} \mathrm{m}^{2} \mathrm{~s}^{-1}$. White indicates zero flux.

In the remaining part of the paper, $F_{\mathrm{HS}}$ and $F_{\mathrm{LS}}$ are referred to as fluxes of high-salinity water and lowsalinity water, respectively.

For the cross-equatorial transports, we will focus the discussion of the different climate scenarios on the annual mean response. Strong variability due to equatorial waves makes the difference in the seasonal cycle less obvious in most cases. At $7^{\circ} \mathrm{N}$ the weaker intraseasonal variability permits a direct comparison of the seasonal cycle of tracers and salinity anomalies.

\section{a. Bay of Bengal tracers and low-salinity water}

In this section the exchange of Arabian Sea water and Bay of Bengal water during extreme events is compared to the normal scenario when the model is forced by the FSU average monthly winds.

The maximum penetration of Bay of Bengal water into the Arabian Sea is seen in April, and the maximum intrusion of Arabian Seawater into the Bay of Bengal appears in October (Jensen 2001b). In both cases, this is the time just before the monsoon reversal. Figure 4 shows the extent of the Bay of Bengal tracer for the climatology and for La Niña and the IOD cases. Note that in case of La Niña, concentrations exceeding 15\% of Bay of Bengal water are advected far into the Ara- bian Sea. For the IOD case, the westward advection is limited, while southward export of Bay of Bengal water along the eastern boundary increased. Also note that the Bay of Bengal water has been completely replaced along the southeast Indian coast. The results support the hypothesis of a strengthening of the clockwise circulation during the IOD and a weakening during La Niña. In a GCM simulation by Rao et al. (2002a) an anomalous clockwise circulation was seen in the Bay of Bengal during September 1997 (see their Fig. 10). The present results corroborate their finding and suggest that this reversed circulation is typical during IOD events.

The maximum intrusion of tracers depends on the cumulative effect of wind stress across the northern Indian Ocean during the entire monsoon season. The wind anomalies are stronger during the IOD than during El Niño while the spatial patterns on average are similar. Consequently, the impact of the IOD on tracer advection is larger than during El Niño, as seen by larger anomalies of passive tracer concentrations.

In the annual mean, the cross-equatorial flux of Bay of Bengal tracer is doubled during an IOD year compared to climatology (Fig. 5), while the flux during La Niña is reduced to about $50 \%$. During El Niño the flux 
is also increased. As noted in Fig. 4, high Bay of Bengal water concentrations extend far into the Arabian Sea in April and May under La Niña and normal conditions. After the onset of the southwest monsoon this lowsalinity water is rapidly advected southward and across the equator by Ekman transport. Figures $6 a-d$ show Hovmöller diagrams of the cross-equatorial Bay of Bengal tracer for the four cases. There is a westward shift in the bulk of the transport during La Niña, which is also seen in the annual mean (Fig. 5). During El Niño and the IOD, the bulk of cross-equatorial transport remains east of Sri Lanka, coming directly from the Bay of Bengal. In all scenarios, the export takes place from May through November. The Bay of Bengal tracer in Figs. 6a-d gives a particularly clear picture of the enhanced cross-equatorial flow.

A section along $7^{\circ} \mathrm{N}$ was used by Jensen (2001b) to examine the intrusion of Bay of Bengal water into the Arabian Sea. The same section is shown in Figs. 6e-h for the four climate scenarios. At the onset of the northeast monsoon, southward advection of Bay of Bengal water takes place along the east Indian coast, followed by intrusion into the Arabian Sea from January to May near $70^{\circ} \mathrm{E}$. In June and July, the deposited Bay of Bengal water is advected southward and eventually moved across the equator (Figs. 6a-d). For the La Niña case the processes of southward advection, followed by northward intrusion and cross-equatorial transport are enhanced. However, the most striking difference is the complete absence of Bay of Bengal water in the Arabian Sea in the IOD case. It was argued by Jensen (2001b, 2003b) that the equatorward Ekman transport driven by the wind right after the onset of the southwest monsoon made it unlikely for Bay of Bengal water to remain in the Arabian Sea. During the IOD Bay of Bengal water does not even get there.

Near the eastern end of the section, the southward export of Bay of Bengal water has a maximum around September by the end of the southwest monsoon. However, note that the maximum export varies from 0.125 $\mathrm{m}^{2} \mathrm{~s}^{-1}$ in the La Niña case to $0.625 \mathrm{~m}^{2} \mathrm{~s}^{-1}$ in El Niño and IOD years.

The net inflow of low-salinity water to the Arabian Sea carried by the Somali Current and its offshore countercurrent is reduced compared to climatology during La Niña (Fig. 7) and slightly larger than normal during El Niño and the IOD, but the differences are fairly small. For the seasonal flux of low-salinity water (Fig. 8), the difference between the cases reflects those shown by the Bay of Bengal tracer, as anticipated. However, note that the low-salinity water intrusion to the Arabian Sea east of $60^{\circ} \mathrm{E}$ during the northeast monsoon does not originate from the Bay of Bengal in the

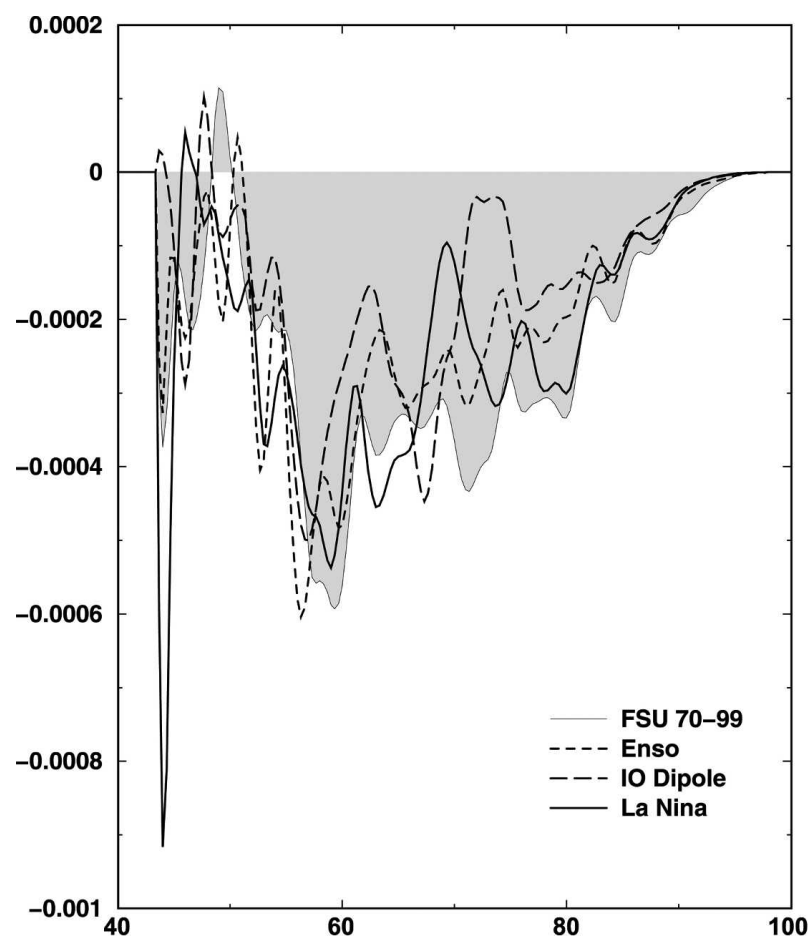

FIG. 9. As in Fig. 7 but for Arabian Sea tracer. Unit is $\mathrm{m}^{2} \mathrm{~s}^{-1}$.

IOD case. We also note that the low-salinity flow in the Somali Current only shows relatively small differences between the four cases.

The source of the low-salinity water entering the Arabian Sea is the equatorial region just south of the equator (Jensen 2001b) as demonstrated using passive tracers and floats (Jensen 2003b). Part of this water originates in the South Equatorial Current via the East African Coastal Current (e.g., Esenkov et al. 2003; Jensen 2003b).

\section{b. Arabian Sea tracers and high-salinity water}

In the annual mean transport of Arabian Sea tracer (Fig. 9), the differences among the climate scenarios are minor changes in the path where the Arabian Sea water crosses the equator. The most significant anomaly is the increased southward cross-equatorial flow of Arabian Sea water in the Somali Current in the La Niña scenario. The magnitude of the export is more than twice the normal export.

Across $7^{\circ} \mathrm{N}$ (Figs. 10a-d) we find that, during La Niña years, southward flux of Arabian Sea water near the west coast of India is reduced, as is the inflow of Arabian Sea water into the Bay of Bengal. Conversely, these fluxes are increased during El Niño events. During the IOD scenario, the flow of the tracer into the Bay of Bengal is further enhanced. 


\section{ARABIAN SEA TRACER FLUX}
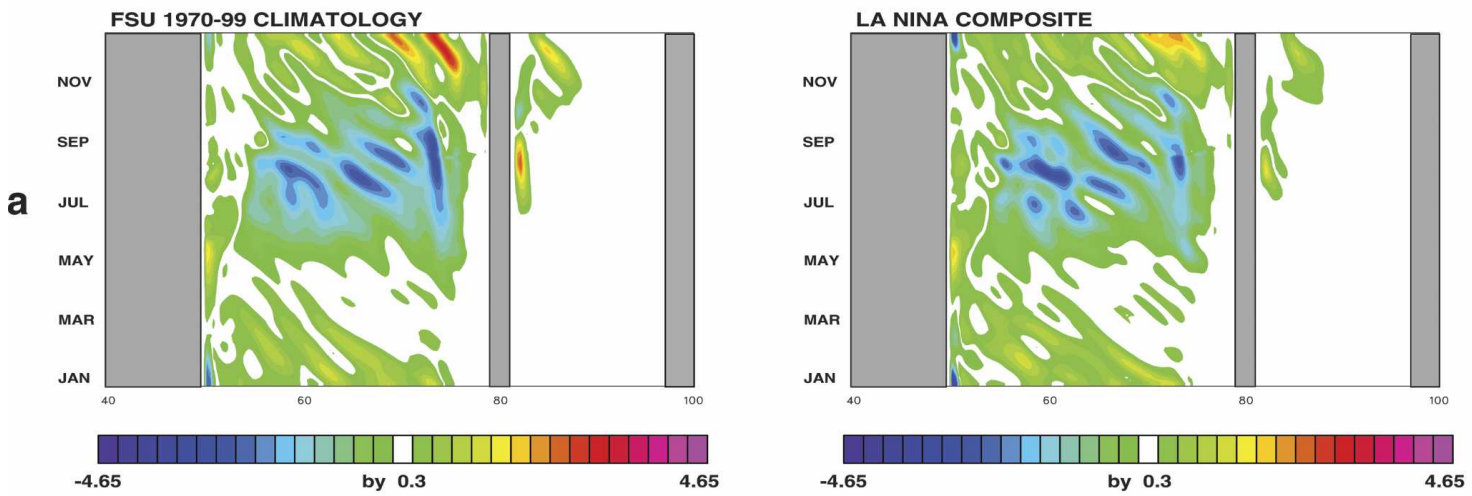

b
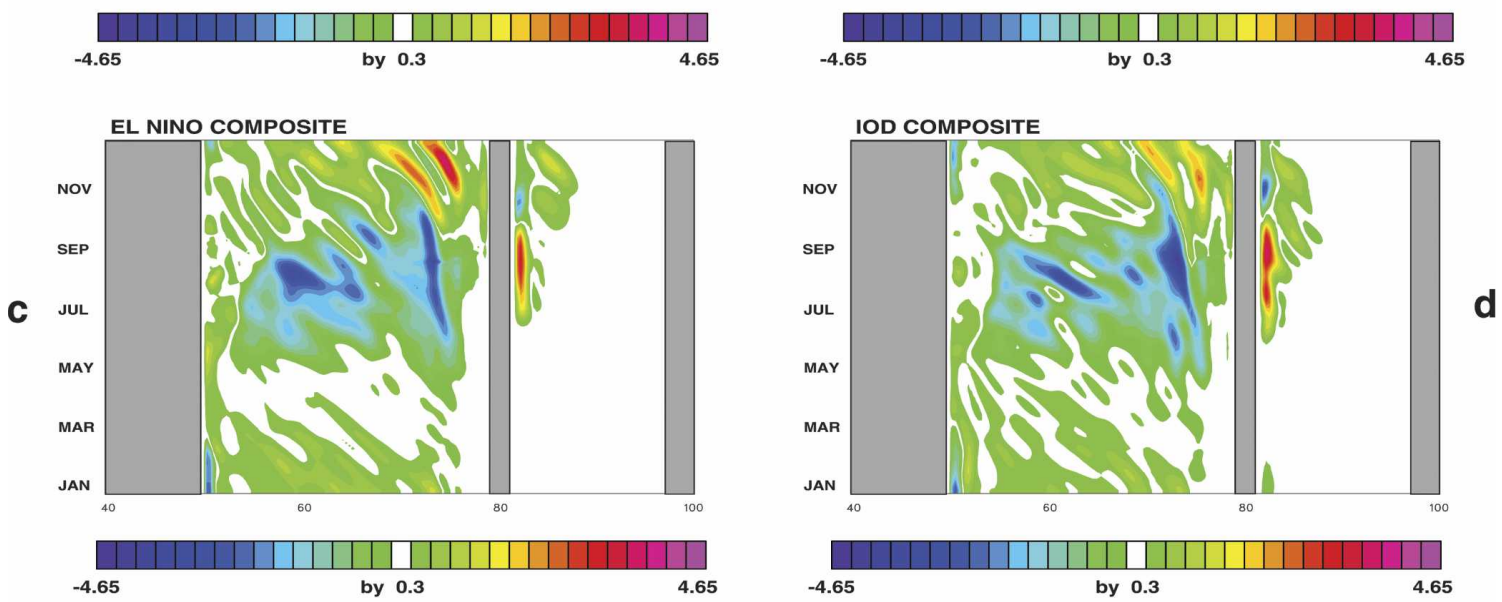

HIGH SALINITY FLUX
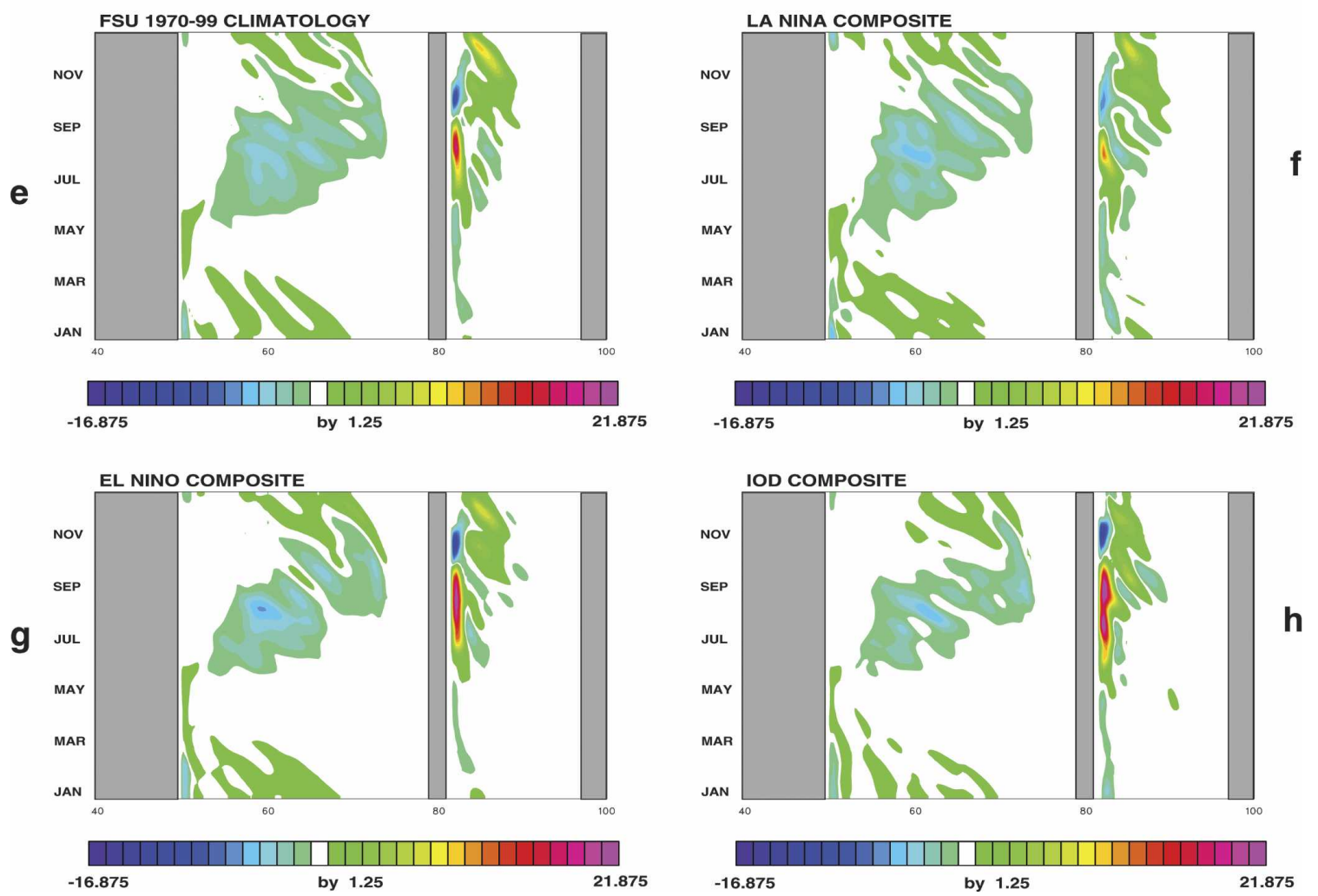


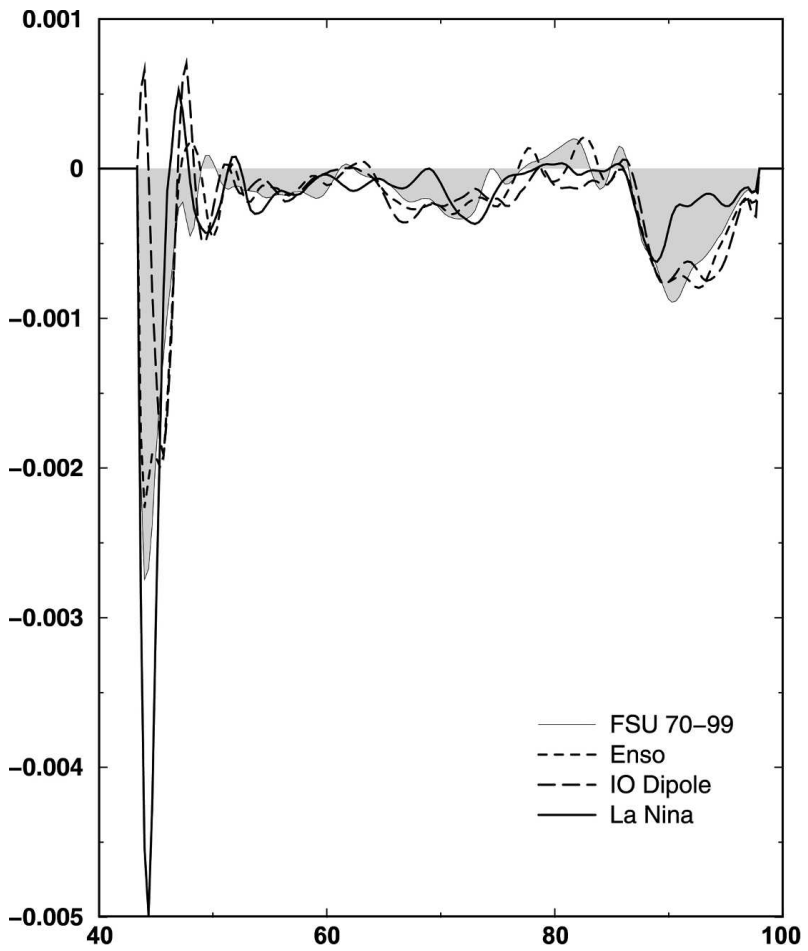

FIG. 11. As in Fig. 7 but for high-salinity water.

High-salinity transports show the same characteristics as the Arabian Sea tracer for these climate events. Figure 11 shows enhanced cross-equatorial flow of southward transport in the Somali Current for La Niña, while it is reduced for the IOD case. At the sections across $7^{\circ} \mathrm{N}$ is an enhanced northward flux into the Bay of Bengal (Figs. 10e-h) during the southwest monsoon, consistent with the enhanced Arabian Sea water intrusion (Fig. 9). Note in Fig. 10e-h that the duration of northward flow along the east Indian coast is longer in the El Niño and IOD cases.

\section{Equatorial surface jets}

During the spring and fall monsoon transition periods strong eastward surface jets appear along the equator (Wyrtki 1973). Figure 12 shows the reversal of the zonal transport in the model solutions. For the climatology, the eastward transport is largest in the central part of the Indian Ocean during the fall jet. Between the spring and the fall eastward jets, westward flow is only found in the western Indian Ocean. For the La
Niña case, the fall jet transport is increased due to longer duration and greater intensity east of $70^{\circ} \mathrm{E}$. However, most significant is the decrease in the fall jet transport during El Niño and IOD. There is a complete reversal after the spring jet to a westward equatorial flow and, in the IOD case, the fall jet is confined to the western Indian Ocean. Vinayachandran et al. (1999) reports the weakening of the eastward equatorial jets during the 1994 IOD event in their OGCM simulation. Using observed drifter data, Grodsky et al. (2001) found a weaker than usual fall jet in 1994 and a reversal during the stronger 1997 IOD event.

The westward anomalous current on the equator is directly driven by the wind anomaly that appears in the eastern Indian Ocean during late summer and fall during the IOD year (Saji et al. 1999). In the next section, the importance of the change from intense eastward flow to a weak westerward flow for the fall jet becomes clear.

\section{Trajectories of surface floats}

All of the results from previous sections support a tendency toward a more intense clockwise circulation of the low-salinity water during El Niño and the IOD. To illustrate the changes in the general circulation in the entire basin we use trajectories of surface floats. This allows us to take into account the seasonal variation of the flow. We use a calculation similar to that used in Jensen (2003b).

Initially one float is positioned in the Bay of Bengal north of $7^{\circ} \mathrm{N}$ for every $1^{\circ}$ in the east-west and $1^{\circ}$ in the north-south direction. A total of 159 floats are used. Using model velocities stored every 3 days during years 5 and 6 from the integration, the position of each float is updated every $12 \mathrm{~h}$ to provide trajectories. The flow fields from years 5 and 6 were used three times to make trajectories for a total of 6 years. The floats remain in the mixed layer throughout the computation unless they run on shore or leave the domain through the open boundaries.

Figure 13a shows the float trajectories from the computation using the model output forced by the La Niña climatology. We note that floats reach far into the Arabian Sea in agreement with the passive tracer computation (Fig. 4). It is also seen that many floats remain in the Bay of Bengal after 5 years, as indicated by the

$\leftarrow$

FIG. 10. Longitude-time plot of northward flux of Arabian Sea tracer anomalies in the mixed layer at $7^{\circ} \mathrm{N}$ during year 5 of the integration forced with wind stress based on (a) FSU 1970-99 climatology, (b) La Niña composite, (c) El Niño composite, and (d) IOD composite. The contour interval is $0.3 \mathrm{~m}^{2} \mathrm{~s}^{-1}$. (e)-(h) Same as in (a)-(d), but for high-salinity water. The contour interval is 1.25 psu $\mathrm{m}^{2} \mathrm{~s}^{-1}$. White indicates zero flux. 

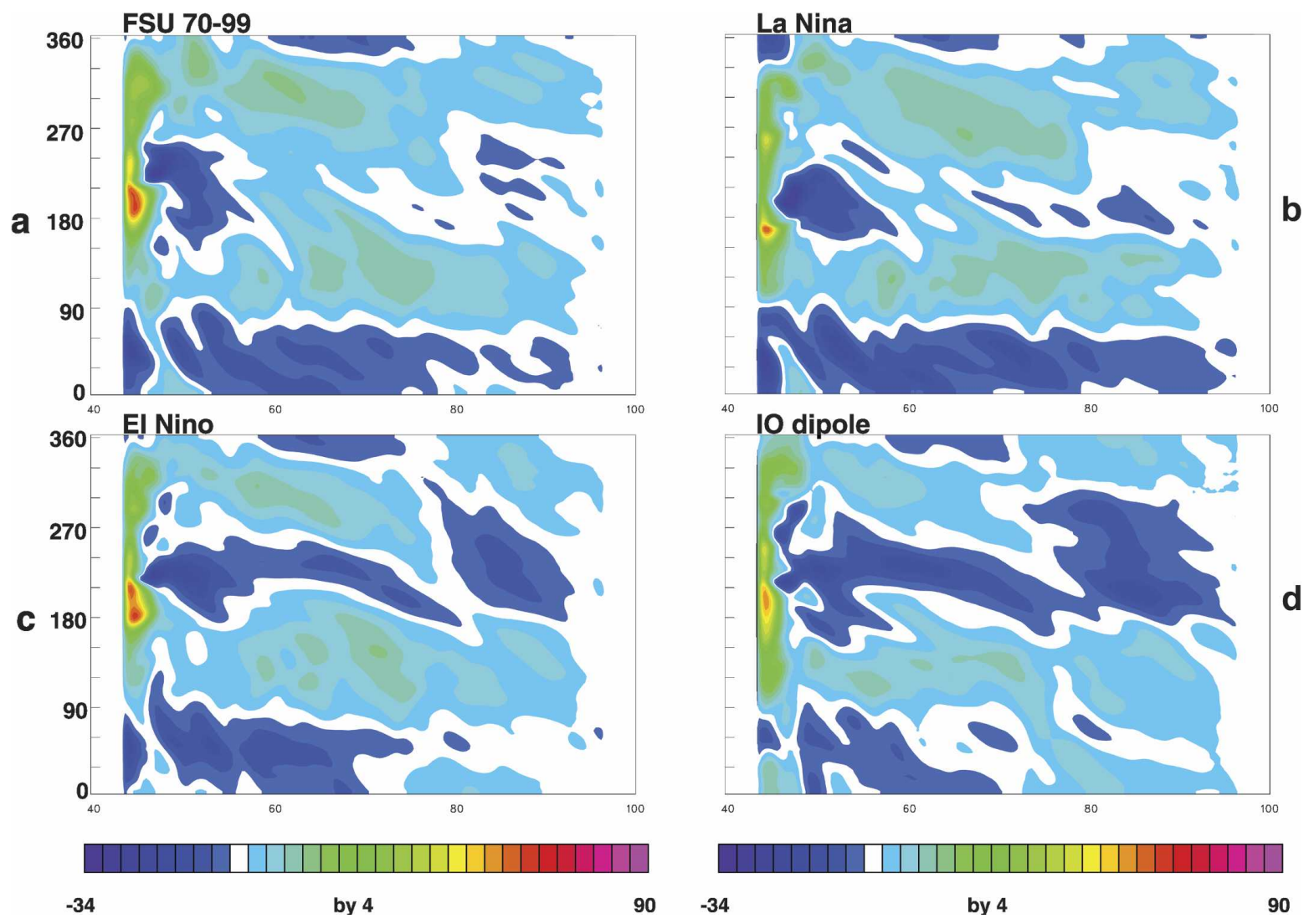

FIG. 12. Longitude-time plot of zonal transport along the equator for the four climatologies: (a) FSU 1970-99, (b) La Niña, (c) El Niño, and (d) IOD. Unit along vertical axis is days. Unit for color scale is $\mathrm{m}^{2} \mathrm{~s}^{-1}$.

large number of yellow trajectories there. We note that only a few floats reach Madagascar in this computation.

In contrast, when forced by IOD climatological winds, a large number of floats leave the Bay of Bengal within two years, as indicated by the blue color in the bay (Fig. 13b). No floats pass $60^{\circ} \mathrm{E}$ on a direct route from the Bay of Bengal. A large number of floats are advected westward in the equatorial region, a consequence of the reversal of the fall Wyrtki jet (Fig. 12). This results in a shorter path back to the western Indian Ocean. As a consequence, a significant number of floats reach the Somali Current within four to six years. Overall, the average advection time through the clockwise gyre has decreased. The El Niño case (not shown) shows a less intense clockwise circulation, but one that is stronger than the climatology. The La Niña case shows the weakest overall circulation.

\section{Summary and discussion}

The wind-driven response to four climate scenariosEl Niño, the Indian Ocean dipole, and La Niña in ad- dition to climatology — has been investigated. A choice was made to relax surface temperature and surface salinity to climatology to get as close to an estimate of a purely wind-driven response as possible. By creating extreme climatologies and using them to force the ocean model over several years, the runs provide equilibrium results for these climate scenarios, similar to perpetual January or July simulations used in meteorology. The model responses shown here should therefore give us some guidelines as to what flows can be expected in models forced by interannual forcing, or in the real ocean, but where the amplitude of the anomalies may be much smaller, and therefore less obvious. Our main results are the following.

In La Niña years, the clockwise circulation in the Indian Ocean is weakened: Less water enters the Bay of Bengal from the Arabian Sea, and less Bay of Bengal water is exported across the equator along the coast of Sumatra. The influx of low-salinity water into the Arabian Sea via the Somali Current is also reduced. On the other hand, the flow of Bay of Bengal water into the Arabian Sea is enhanced. In contrast, the clockwise 

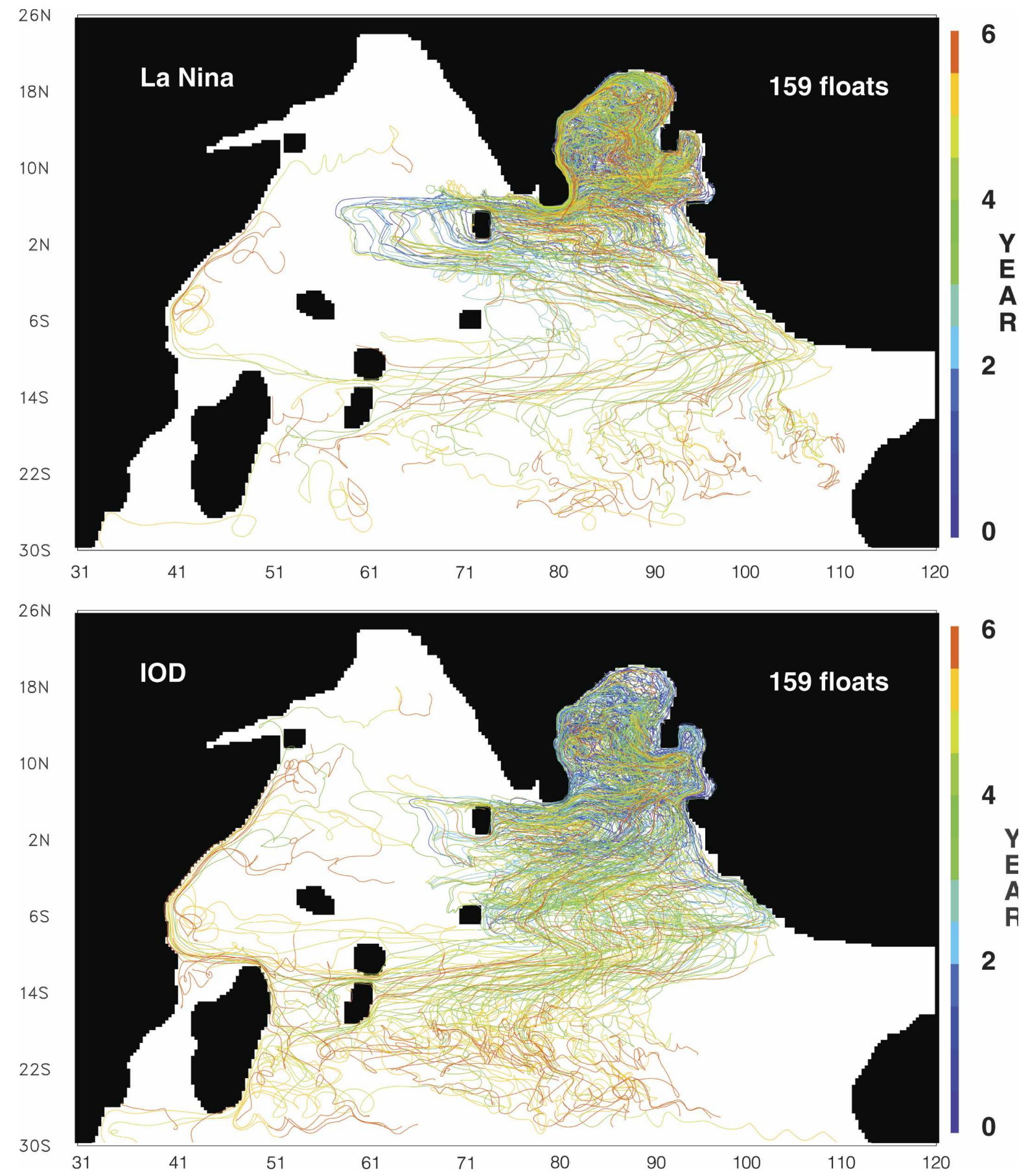

FIG. 13. Float trajectories in the mixed layer computed from a run forced (top) with La Niña climatological wind stress and (bottom) with IOD climatological wind stress. Each color change on the age scale corresponds to a 3-month time interval. All floats originate in the Bay of Bengal.

mean circulation is enhanced during El Niño: Arabian Sea water deposits into the Bay of Bengal are increased, as is the cross-equatorial flow along the eastern basin boundary of low-salinity water from the Bay of Bengal (Figs. 3, 5). The flow toward the Arabian Sea from the Bay of Bengal during the northeast monsoon is much reduced, further inhibiting the westward pathway of freshwater in the northern Indian Ocean. During an IOD event, the clockwise circulation is even further enhanced. 
In the solutions the Indonesian Throughflow has been held close to a constant $10 \mathrm{~Sv}$. From observations it has been found that the transport increases during $\mathrm{La}$ Niña and decreases during El Niño (Meyers 1996). This would tend to counteract the conclusions about the variations in the strength in the clockwise circulation supported by these model studies, and the main reason why no attempt has been made to make more detailed analysis or conclusions about the Southern Hemisphere flow in this study. However, calculations using floats support the results using passive tracers in the northern Indian Ocean: The clockwise circulation is intensified during El Niño and the IOD scenario and is weakened during La Niña. The results presented here are wind driven. Changes in buoyancy fluxes may change these results to some extent, although the strong wind forcing, which dominates the Indian Ocean circulation makes this less likely. It can rightfully be argued that the solutions given here are artificial since consecutive El Niño, La Niña, or IOD years never occur in nature. The intention here is simply to determine the tendency of the circulation that each of these climates favors.

Acknowledgments. This research was supported by the Japan Agency for Marine-Earth Science and Technology (JAMSTEC) through its sponsorship of the International Pacific Research Center (IPRC).

\section{REFERENCES}

Baquero-Bernal, A., M. Latif, and S. Legutke, 2002: On dipolelike variability of sea surface temperature in the tropical Indian Ocean. J. Climate, 15, 1358-1368.

Behera, S. K., S. A. Rao, N. H. Saji, and T. Yamagata, 2003: Comments on "A cautionary note on the interpretation of EOFs." J. Climate, 16, 1087-1093.

Clark, C. O., P. J. Webster, and J. Cole, 2003: Interdecadal variability of the relationship between the Indian Ocean zonal mode and East African rainfall anomalies. J. Climate, 16, $548-554$.

Esenkov, O. E., D. B. Olson, and R. Bleck, 2003: A study of the circulation and salinity budget of the Arabian Sea with an isopycnic coordinate ocean model. Deep-Sea Res. II, 50, 2091-2110.

Feng, M., and G. Meyers, 2003: Interannual variability of the tropical Indian Ocean. Deep-Sea Res. II, 50, 2263-2284.

Grodsky, S. A., J. A. Carton, and R. Murtugudde, 2001: Anomalous surface currents in the tropical Indian Ocean. Geophys. Res. Lett., 28, 4207-4210.

Haugen, V. E., O. M. Johannesen, and G. Evensen, 2002: Indian Ocean: Validation of the Miami Isopycnic Coordinate Ocean Model and ENSO events during 1958-1998. J. Geophys. Res., 107, 3043, doi:10.129/2000JC000330.

Jensen, T. G., 1991: Modeling the seasonal undercurrents in the Somali current system. J. Geophys. Res., 96, 22 151-22 167.
, 1993: Equatorial variability and resonance in a wind-driven Indian Ocean model. J. Geophys. Res., 98, 22 533-22 552.

_ 1998a: Description of a Thermodynamic Ocean Modelling System (TOMS). Atmospheric Science Paper 670, Colorado State University, Fort Collins, CO, 50 pp.

_ 1998b: Open boundary conditions in stratified ocean models. J. Mar. Syst., 16, 297-322.

— 2001a: Application of the GWR method to the tropical Indian Ocean. Mon. Wea. Rev., 129, 470-485.

_ 2001b: Arabian Sea and Bay of Bengal exchange of salt and tracers in an ocean model. Geophys. Res. Lett., 28, 3967-3970.

_ 2003a: Barotropic mode errors in an Indian Ocean model associated with the GWR method. Global Planet. Change, 37, $1-18$.

- 2003b: Cross-equatorial pathways of salt and tracers from the northern Indian Ocean: Modelling results. Deep-Sea Res. II, 50, 2111-2127.

Lau, N.-C., and M. J. Nath, 2004: Coupled GCM simulation of atmosphere-ocean variability associated with zonally asymmetric SST changes in the tropical Indian Ocean. J. Climate, 17, 245-265.

Levitus, S., and T. P. Boyer, 1994: Temperature. Vol. 4, World Ocean Atlas 1994, NOAA Atlas NESDIS 4, 117 pp.

_, R. Burgett, and T. P. Boyer, 1994: Salinity. Vol. 3, World Ocean Atlas 1994, NOAA Atlas NESDIS 3, 99 pp.

Manghnani, V., B. Subrahmanyam, L. Xie, and J. M. Morrison, 2003: Numerical simulation of seasonal and interannual Indian Ocean upper layer circulation using Miami Isopycnic Coordinate Ocean Model. J. Geophys. Res., 108, 3240, doi:10.1029/2002JC001567.

Meyers, G., 1996: Variation of Indonesian throughflow and El Niño-Southern Oscillation. J. Geophys. Res., 101, 12255 12263.

Miyama, T., J. P. McCreary, T. G. Jensen, J. Loschnigg, S. Godfrey, and A. Ishida, 2003: Structure and dynamics of the Indian Ocean cross-equatorial cell. Deep-Sea Res. II, 50, 20232047.

Murtugudde, R. G., J. P. McCreary, and A. J. Busalacchi, 2000: Oceanic processes associated with anomalous events in the Indian Ocean with relevance to 1997-1998. J. Geophys. Res., 105, 3295-3306.

Rao, S. A., and S. K. Behera, 2005: Subsurface influence on SST in the tropical Indian Ocean: Structure and interannual variability. Dyn. Atmos. Oceans, 39, 103-135.

,,-- Y. Masumoto, and T. Yamagata, 2002a: Interannual subsurface variability in the tropical Indian Ocean with special emphasis on the Indian Ocean Dipole. Deep-Sea Res. II, 49, 1549-1572.

—, V. V. Gopalakrishna, S. R. Shetye, and T. Yamagata, 2002b: Why were cool SST anomalies absent in the Bay of Bengal during the 1997 Indian Ocean dipole event? Geophys. Res. Lett., 29, 1555, doi:10.1029/2001GL014645.

Saji, N. H., and T. Yamagata, 2003a: Possible impacts of Indian Ocean dipole mode events on global climate. Climate Res., 25, 151-169.

$\longrightarrow$, and — 2003b: Structure of SST and surface wind variability during Indian Ocean dipole mode events: COADS observations. J. Climate, 16, 2735-2751.

_ , B. N. Goswami, P. N. Vinayachandran, and T. Yamagata, 1999: A dipole in the Indian Ocean. Nature, 401, 360-363. 
Shinoda, T., and M. A. Alexander, 2004: Remote response of the Indian Ocean to interannual SST variations in the tropical Pacific. J. Climate, 17, 362-372.

Smagorinsky, J., 1963: General circulation experiments with the primitive equations. I. The basic experiment. Mon. Wea. Rev., 91, 99-164.

Vinayachandran, P. N., N. H. Saji, and T. Yamagata, 1999: Response of the equatorial Indian Ocean to an unusual wind event during 1994. Geophys. Res. Lett., 26, 1613-1616.

— , S. Iizuka, and T. Yamagata, 2002: Indian Ocean dipole mode events in an ocean general circulation model. Deep-Sea Res. II, 49, 1573-1596.

Webster, P. J., A. M. Moore, J. P. Loschnigg, and R. R. Leben, 1999: Coupled ocean-atmosphere dynamics in the Indian Ocean during 1997-98. Nature, 401, 356-360.

Wyrtki, K., 1973: An equatorial jet in the Indian Ocean. Science, 182, 262-264.

Xie, S.-P., H. Annamalai, F. A. Schott, and J. P. McCreary, 2002: Structure and mechanisms of south Indian Ocean climate variability. J. Climate, 15, 864-878. 